\title{
The Protective Role of Vitamin C Against Cerebral and Pulmonary Damage Induced by Cadmium Chloride in Male Adult Albino Rat
}

\author{
Gamal H. El-Sokkary*,1 and Eatemad A. Awadalla ${ }^{2}$ \\ ${ }^{1}$ Department of Zoology, Faculty of Science, Assiut University, 71516 Assiut-Egypt; ${ }^{2}$ Department of Zoology, Aswan \\ Faculty of Science, South Valley University, Aswan-Egypt
}

\begin{abstract}
This study was designed to examine the protective role of vitamin C (VC) against oxidative stress and morphological changes induced by chronic exposure to cadmium chloride $\left(\mathrm{CdCl}_{2}\right)$ in the lungs and brain. Male adult rats received $\mathrm{CdCl}_{2}(5 \mathrm{mg} / \mathrm{kg}$ body weight) daily for forty days. Vitamin $\mathrm{C}$ (VC) at a dose of $100 \mathrm{mg} / \mathrm{kg}$ body weight was given concomitantly with $\mathrm{CdCl}_{2}$ to the rats. Three animal groups were used in this experiment (control, $\mathrm{CdCl}_{2}$ and $\mathrm{CdCl}_{2}+\mathrm{VC}$ ). The concentration of malondialdehyde (MDA), activity of superoxide dismutase (SOD) enzyme and concentration of glutathione (GSH) were measured in the lung and brain homogenates. Also, histopathological investigations were carried out in lung and brain tissues. $\mathrm{CdCl}_{2}$ administration significantly increased the levels of MDA and decreased the activity of SOD and GSH concentration in the lungs and brain versus those of control rats. Administration of vitamin $\mathrm{C}$ counteract the changes of all measured parameters and appear nearly like those of controls. Light microscopy revealed marked changes in the structure of the studied tissues of $\mathrm{CdCl}_{2}$ administered animals. Again, vitamin $\mathrm{C}$ restored the damage of tissues associated with $\mathrm{CdCl}_{2}$ administration. The present results suggest that vitamin $\mathrm{C}$ administration attenuated the oxidative damage and morphological changes induced by $\mathrm{CdCl}_{2}$ in the lungs and brain of rats.
\end{abstract}

Keywords: Cadmium, vitamin C, brain, lungs, lipid peroxidation, superoxide dismutase, glutathione.

\section{INTRODUCTION}

Cadmium $(\mathrm{Cd})$ is a highly toxic element that is naturally present in all parts of the environment, including food, water, and soil [1]. It is extracted during the production of other metals, such as zinc, lead and copper and it is used in industrial and household products, mainly in batteries, pigments, metal coatings, plastics and some metal alloys $[2,3]$. The main source of toxic exposure of cadmium is by the inhalation route of cadmium particles or fumes during industrial operations [4,5]. It is also present in cigarette smoke, representing a significant source of exposure [6].

Cadmium accumulates and proves to cause severe damage to a variety of organs such as lung, brain, testis, kidney, liver, blood system and bone [7-9]. Pneumonitis, pulmonary emphysema, interstitial fibrosis together with cancer are a frequent response to cadmium exposure [10,11]. Because of its characteristics as a lung carcinogen, cadmium has been classified as a category 1 carcinogen (human carcinogen) by the International Agency for Research on Cancer and the National Toxicology Program of the USA [12].

Acute inhalation of sufficient exposure of cadmium can cause both a chemical pneumonitis and pulmonary edema from the toxic effect to the alveolar epithelium and endothelium [13]. Within $24 \mathrm{~h}$ of exposure, workers develop

*Address correspondence to this author at the Department of Zoology, Faculty. of Science, Assiut University, 71516 Assiut-Egypt;

Tel: ++ 088-2401724; Fax: ++ 088-2342708;

E-mail: Elsokkary2000@yahoo.com shortness of breath, fever, and fatigue, which can progress to pulmonary edema and death [14]. Chronic exposure to cadmium dusts and fumes has been suspected as a cause of emphysema, obstructive lung disease, pulmonary fibrosis, and lung cancer.

Exposure of adult rats to low or moderate doses of $\mathrm{Cd}$ induced lipid peroxidation (LPO) in all tissues, mainly lung and brain [7]. Monroe and Halvorsen [15] provided evidence that $\mathrm{CdCl}_{2}$ increases oxidative stress in nervous cells. The brain is particularly sensitive to oxidative damage because of its high rate of oxidative metabolism [16]. Cd also enhances the production of free radicals in the brain of adult rats and interferes with the antioxidant defense system that in turn leads to a Cd-induced alteration of the structural integrity of lipids [17]. In adult rats co-exposed to $\mathrm{Cd}$, there was an increase of LPO in the corpus striatum and cerebral cortex [18]. Cd also induces a significant increase of free radicals production and LPO in brain of developing rats [19].

$\mathrm{Cd}$ (II) accumulates and is toxic in many organs, including kidneys, lungs and testis [20,21]. Nishimura et al. [22] reported that $\mathrm{Cd}(\mathrm{II})$ can enter into the brain parenchyma and neurons and causes neurological alterations in humans [23] and animal models [24], leading to lower attention, hypernociception, olfactory dysfunction and memory deficits. Moreover, $\mathrm{Cd}$ induced cerebral hemorrhage and cerebral edema in neonatal rats [25]. In experimental studies with animals, cadmium is able to induce neurotoxicity with a wide spectrum of clinical entities including neurological disturbance [26], changes in the normal neurochemistry of the brain [27]. 
Several authors have shown that antioxidants should be one of the important components of an effective treatment of cadmium poisoning [28-30]. Accordingly, to prevent undesired oxidative damage induced by reactive species, organisms are equipped with several lines of antioxidant defense. Vitamin $\mathrm{C}$ is an aqueous phase antioxidant has been established for many decades and has several important roles. It modulates intracellular redox status through maintaining sulphydryl compounds, including glutathione, in their reduced state. It has been suggested to repair protein hydroperoxides, through regeneration of parent amino acids by reduction. Also, it serves to maintain membrane alpha tocopherol and enzyme activities including hepatic mixed function oxidase activity [31]. Ascorbic acid, after being converted to dehydroascorbic acid by free radical reactions, is regenerated via the glutathione enzyme complex [32]. Gupta and Kar [33] reported that vitamin C can prevent increased lipid peroxidation levels resulting from cadmium toxicity. Vitamin $\mathrm{C}$ could serve as an effective antioxidant against restraint stress induced pro-oxidant status and increase the antioxidant enzyme activity in rat brain [34] and liver [35].

The present study has implicated the importance of antioxidants such as vitamin $\mathrm{C}$ in protecting living organism against the toxic effect of cadmium exposure.

\section{MATERIALS AND METHODS}

\subsection{Experimental Animals}

Thirty adult male Sprague-Dawley rats weighting 100$120 \mathrm{~g}$ were used in the present work. The animals were purchased from Aboraoash Joint Animal Breeding Unit. The animals were kept in a controlled light room with a photoperiod of 12 hours dark and 12 hours light (dark light cycle $12: 12$ ) at a temperature of $28 \pm 2{ }^{\circ} \mathrm{C}$. All animals were given free access to standard laboratory chow and tap water.

\subsection{Chemicals}

Cadmium chloride $\left(\mathrm{CdCl}_{2}, 99 \%\right.$ pure $)$ was purchased from Aldrich Chemical Co. Cadmium chloride was dissolved in saline solution $(0.9 \% \mathrm{NaCl})$. Ascorbic acid, dimethyl sulfoxide, Sodium dodecyl sulphate (SDS), Thiobarbituric acid (TBA) and epinephrine were purchased from Sigma Chemical Co. (St. Louis, MO, USA). Ascorbic acid (Vitamin C) was dissolved in distilled water. All other chemicals were of the highest purity commercially available.

\subsection{Experimental Design:} each:

The rats were randomly divided into three groups, 10 rats

- The first group: designated $\mathrm{Cd}$, was injected subcutaneously with cadmium chloride at a dose of 5 $\mathrm{mg} / \mathrm{kg}$ body weight.

- The second group: designated $\mathrm{Cd}+\mathrm{VC}$, was injected subcutaneously with vitamin $\mathrm{C}$ at a dose of $100 \mathrm{mg} / \mathrm{kg}$ body weight. The administration of vitamin $\mathrm{C}$ was 30 min. before $\mathrm{Cd}$ injection and was given at 8 a.m.

- The third group: served as controls and the rats were injected with vehicles only.

- All the above injections were repeated daily for 40 days.

\subsection{Tissue Preparations}

The specimens from the selected organs (lungs and brain) were rapidly excised, and cut conveniently into small pieces, which were used for histology and histopathology. Another portions of the studied organs were frozen at $-40{ }^{\circ} \mathrm{C}$ for measurement of lipid peroxidation (LPO) which is an oxidative stress indicator.

\subsection{Measurement of Lipid Peroxidation}

The method of measurement of oxidized lipids was based on that of Ohkawa et al. [36] using 1,1,3,3-tetramethoypropane as standard. A $10(\mathrm{w} / \mathrm{v})$ tissue homogenate from brain and lungs required for this assay (this homogenate contained $1 \% \mathrm{v} / \mathrm{v}$ dimethyl sulfoxide to prevent further oxidation). To $0.2 \mathrm{ml}$ aliquots of tissue homogenate was added $0.2 \mathrm{ml} 8.1 \% \mathrm{w} / \mathrm{v}$ sodium dodecyl sulfate solution, 1.5 $\mathrm{ml} \mathrm{20 \%} \mathrm{v/v} \mathrm{acetic} \mathrm{acid} \mathrm{solution} \mathrm{(PH} \mathrm{3.5)} \mathrm{and} 1.5 \mathrm{ml} 0.8 \%$ $\mathrm{w} / \mathrm{v}$ thiobarbituric acid solution. The mixture was made up to $4.0 \mathrm{ml}$ with distilled water and heated to $95{ }^{\circ} \mathrm{C}$ for $1 \mathrm{~h}$. The samples were cooled and centrifuged at $2000 \mathrm{xg}$ for $10 \mathrm{~min}$ and absorbance measured at $532 \mathrm{~nm}$. Results were expressed as $\mathrm{n}$ mol malondialdehyde formation per $\mathrm{g}$ tissue.

\subsection{Superoxide Dismutase (SOD) Activity}

SOD activity was determined at room temperature according to the method of Misra and Fridovich [37]. Ten microlitres of tissue extract was added to $970 \mathrm{ml}(0.05 \mathrm{M}$, pH 10.2, 0.1 mM EDTA) sodium carbonate buffer. Twenty microlitres of $30 \mathrm{mM}$ epinephrine (dissolved in $0.05 \%$ acetic acid) was added to the mixture to start the reaction. SOD was measured at $480 \mathrm{~nm}$ for $4 \mathrm{~min}$. Activity was expressed as the amount of enzyme that inhibits the oxidation of epinephrine by $50 \%$, which is equal to 1 unit, per mg protein.

\subsection{Measurement of Glutathione (GSH) Concentration}

GSH content was measured by a modification of the method of Beutler et al. [38]. Briefly, $500 \mu \mathrm{l}$ of tissue extract was added to $2.0 \mathrm{ml}$ of $0.2 \mathrm{M}$ phosphate buffer and $0.25 \mathrm{ml}$ $0.04 \%$ 5,5' dithio-bis 2-nitrobenzoic acid. Absorbance was read at $410 \mathrm{~nm}$. GSH content was expressed as nanomoles of GSH per $\mathrm{mg}$ of protein. Protein concentrations were measured by the method of Bradford [39] using bovine albumin as standard..

\subsection{Histological and Histopathological Examinations}

For the histological and histopathological examinations, pieces of the organs were fixed in $10 \%$ of neutral buffered formalin ( $\mathrm{pH}$ 7.2), dehydrated in ascending series of ethanol, cleared in methyl benzoate and embedded in paraffin wax. Paraffin sections of 5 microns in thickness were prepared and stained with Harris's haematoxlin and eosin [40].

\subsection{Statistical Analysis}

Results of LPO were expressed as means \pm S.E.M Differences between means were tested by the ANOVA followed by the Student-Newman-Keuls t-test. The percent of stimulation ( $\mathrm{S} \%)$ or inhibition $(\mathrm{I} \%)$ in the mean values of LPO was calculated. 


\section{RESULTS}

Quantitative results of cadmium oxidative stress induction in the lungs and brain of control and different treated animal groups were presented in Tables $\mathbf{1}$ and $\mathbf{2}$. As shown, administration of cadmium significantly increased $(\mathrm{P}<0.01)$ LPO levels (as indicated by the increase in malondialdehyde [MDA] levels) in the homogenates of the lungs and brain versus those of control rats by $53.6 \%$ and $68.8 \%$, respectively. When vitamin $\mathrm{C}$ was given (30 minutes before cadmium) to cadmium-administered rats, it significantly inhibited $(\mathrm{P}<0.01)$ the increase of MDA by $47.4 \%$ and $45.8 \%$ in the lungs and brain, respectively.

The activity of SOD was severely inhibited $(\mathrm{P}<0.01)$ in the lungs and brain homogenates of cadmium-administered animals versus those of controls. The cadmium-induced inhibition of SOD activity was $38.6 \%$ and $48.2 \%$ in the lungs and brain, respetively. The administration of vitamin $\mathrm{C}$ to rats which given cadmium markedly stimulated $(\mathrm{P}<0.01)$ the activity of SOD by $33.6 \%$ and $32.9 \%$ in both the lungs and brain.

Cadmium administration to the rats reduced total GSH concentrations $(\mathrm{P}<0.01)$ in the lungs and brain compared to those of controls by $51.5 \%$ and $49.4 \%$, respectively. In contrast, vitamin $\mathrm{C}$ administration to cadmium-administered rats markedly restored $(34.8 \%$ and $31.6 \%)$ the concentrations of GSH $(\mathrm{P}<0.01)$ in the lungs and brain, respectively.

Histopathological examination revealed marked destruction of both lungs and brain tissues. In the lungs, administration of $\mathrm{Cd}$ induced severe changes (Fig. 1B) versus those of controls (Fig. 1A). The changes include thickened-walled alveoli and alveolar septa, infiltration of a huge number of inflammatory cells and exudation in many places as shown in Fig. (1B). When vitamin $\mathrm{C}$ was given to $\mathrm{Cd}$-administered rats, it restored these changes and the lung tissue appear nearly like those of control rats as shown in Fig. (1C). In the brain, $\mathrm{Cd}$ induced massive damage in the hippocampus and cerebral cortex (Figs. 2B and 3B) versus those of control animals (Figs. 2A and $\mathbf{3 A}$ ) respectively. The most obvious changes are cellular atrophy, shrinkage, cellular necrosis, pyknosis, deeply stained and dark nuclei as shown in Figs. (2B) and (3B). Again, vitamin C administered-rats exhibited more or less normal neurons in both hippocampus and cerebral cortex compared with those of Cd-group (Figs. 2C and 3C).

\section{DISCUSSION}

Cadmium $(\mathrm{Cd})$ is known to produce a variety of health hazards in humans and experimental animals due to its ability to induce severe alterations in various organs and tissues including the nervous system, following either acute or chronic exposure [7]. Inhalation of $\mathrm{Cd}$ can cause pulmonary emphysema, fibrosis, and lung carcinomas in human and experimental models [41]. It promotes an early oxidative stress and afterward contributes to the development of serious pathological conditions [42]. The mechanism by which cadmium causes toxicity is far from

Table 1. Mean Values \pm S.E.M of Lipid Peroxidation Product (MDA), Superoxide Dismutase (SOD), Glutathione (GSH) and Inhibition (I) and/or Stimulation (S) \% in the Lungs Homogenates of Control and Different Treated Groups of Rats

\begin{tabular}{|c|c|c|c|}
\hline Measurements & $\begin{array}{c}\text { MDA } \\
\text { (nmol/g Tissue) }\end{array}$ & $\begin{array}{c}\text { SOD } \\
\text { (Units/mg Protein) }\end{array}$ & $\begin{array}{c}\text { GSH } \\
\mu \text { gm/mg Protein }\end{array}$ \\
\hline \hline Groups & $3.747 \pm 0.172^{\mathrm{a}}$ & $1.162 \pm 0.067^{\mathrm{a}}$ & $0.0181 \pm 0.0007^{\mathrm{a}}$ \\
\hline Control (n=10) & $8.079 \pm 0.475^{\mathrm{b}}$ & $0.714 \pm 0.034^{\mathrm{b}}$ & $0.0088 \pm 0.0004^{\mathrm{b}}$ \\
\hline Cadmium (n=10) & $\mathrm{S}=53.6$ & $\mathrm{I}=38.6$ & $\mathrm{I}=51.5$ \\
\hline I or S\% vs control & $4.247 \pm 0.323^{\mathrm{ac}}$ & $1.075 \pm 0.053^{\mathrm{c}}$ & $0.0135 \pm 0.0004^{\mathrm{c}}$ \\
\hline Cd+Vitamin C (n=10) & $\mathrm{I}=47.4$ & $\mathrm{~S}=33.6$ & $\mathrm{~S}=34.8$ \\
\hline I or S\% vs Cd & & \\
\hline
\end{tabular}

S.E.M: standard error of the mean. Values in the same columns with unlike superscript letters significantly differ.

Table 2. Mean Values \pm S.E.M of Lipid Peroxidation Product (MDA), Superoxide Dismutase (SOD), Glutathione (GSH) and Inhibition (I) and/or Stimulation (S) \% in the Brain Homogenates of Control and Different Treated Groups of Rats

\begin{tabular}{|c|c|c|c|}
\hline Measurements & $\begin{array}{c}\text { MDA } \\
\text { Groups }\end{array}$ & $\begin{array}{c}\text { SOD } \\
\text { (Units/mg Protein) }\end{array}$ & $\begin{array}{c}\text { GSH } \\
\mu \text { Tissue })\end{array}$ \\
\hline \hline Control $(\mathrm{n}=10)$ & $1.984 \pm 0.161^{\mathrm{a}}$ Protein & $1.995 \pm 0.057^{\mathrm{a}}$ & $0.0214 \pm 0.0001^{\mathrm{a}}$ \\
\hline Cadmium (n=10) & $6.233 \pm 0.534^{\mathrm{b}}$ & $1.033 \pm 0.046^{\mathrm{b}}$ & $\mathrm{I}=49.4$ \\
\hline $\mathrm{I}$ or S\% vs control & $\mathrm{S}=68.8$ & $\mathrm{I}=48.2$ & $0.0108 \pm 0.0005^{\mathrm{b}}$ \\
\hline $\mathrm{Cd}+\mathrm{Vitamin} \mathrm{C}(\mathrm{n}=10)$ & $3.377 \pm 0.488^{\mathrm{ac}}$ & $1.539 \pm 0.062^{\mathrm{c}}$ & $\mathrm{S}=31.6$ \\
\hline I or S\% vs Cd & $\mathrm{I}=45.8$ & $\mathrm{~S}=32.9$ & \\
\hline
\end{tabular}

S.E.M: standard error of the mean. Values in the same columns with unlike superscript letters significantly differ. 


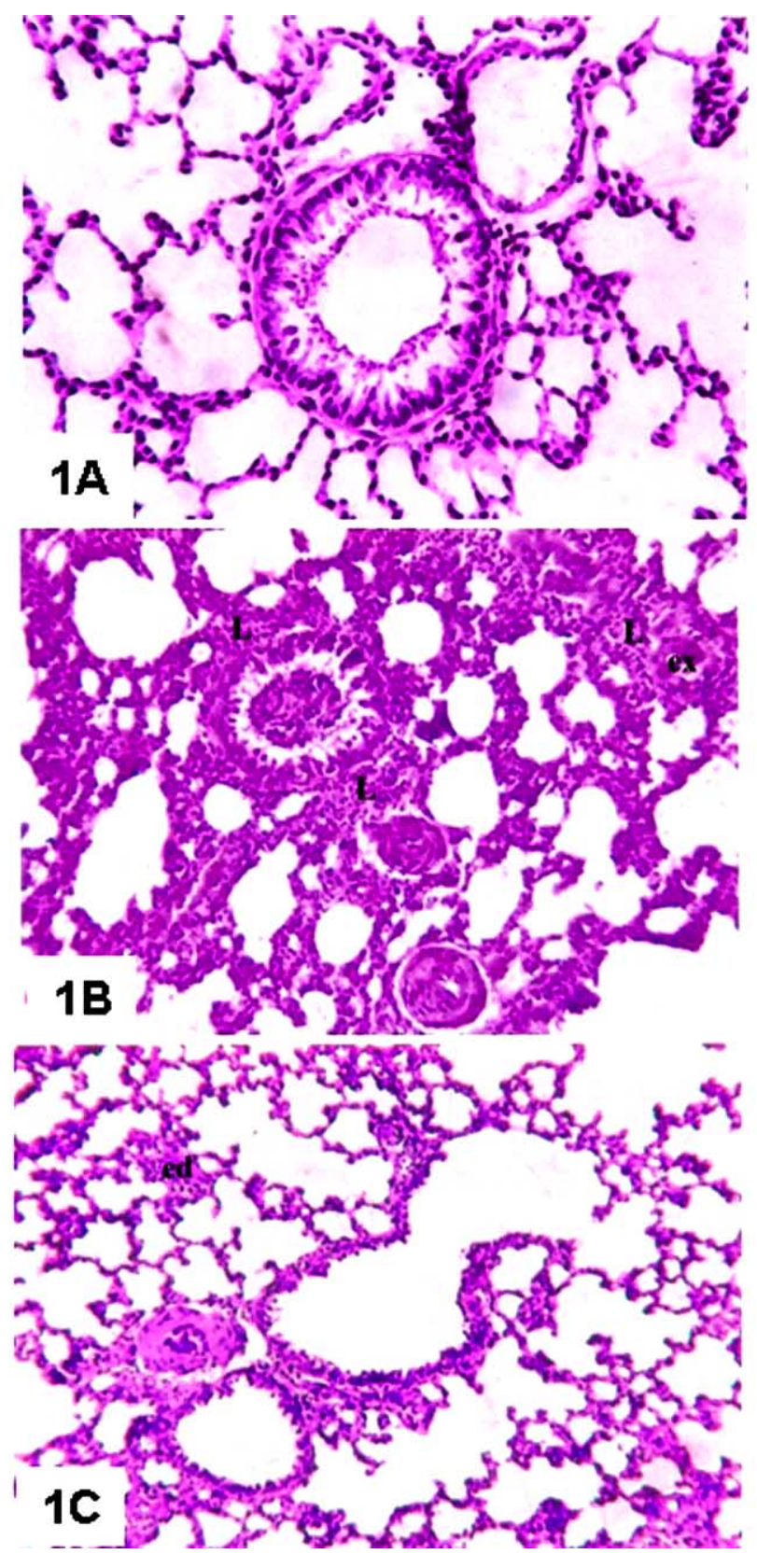

Fig. (1). (A) Lung section of a control rat showing sponge-like appearance of the bronchial tree and normal respiratory tissue. (H\&E X 400). (B) Lung section of Cd-administered rat displaying marked thickness of the alveolar septa, infiltration of inflammatory cells (L) and some exudation (ex). (H\&E X 400). (C) Lung section of $\mathrm{VC}+\mathrm{Cd}$-treated rat showing nearly normal architecture of the respiratory tissue with edema (ed) in some regions. (H\&E X 400).

being completely understood, although lipid peroxidation (LPO) has long been considered to be the primary mechanism for cadmium toxicity [7]. Among the various effects induced by $\mathrm{Cd}$ in biological systems, the oxidative destruction of membrane polyunsaturated fatty acids, a phenomenon termed LPO, has been observed in numerous tissues both in vitro and in vivo [43]. The oxidative stress which contributes to the pathogenesis of cadmium toxicity is the consequence of either enhanced ROS production or attenuated ROS scavenging capacity resulting in tissue damage that is most easily assessed by measuring lipid peroxide levels $[44,45]$.

In the present study, we found a significant increase in the levels of LPO and a significant decrease in both SOD activity and GSH concentration in the lungs and brain of cadmium-exposed rats compared to those of controls. Our results are in harmony with those of Luchese et al. [10] and El-Sokkary et al. $[29,30]$ who found that cadmium induced oxidative damage which had been demonstrated by the previous parameters. Furthermore, several studies demonstrated that, LPO may be one of the important events responsible for pulmonary and cerebral toxicity of $\mathrm{Cd}[7,8]$. The lung, because of its interface with the environment, is a major target organ for injury by exogenous oxidants such as environmental pollutants, cigarette smoke, drugs, chemotherapeutic agents and hyperoxia, as well as by endogenous ROS generated by inflammatory cells. Yang et al. [46] reported that $\mathrm{Cd}$ is able to cause oxidative cellular damage in lung fibroblasts, manifested by lipid peroxidation, elevated level of ROS formation, and mitochondrial membrane damage, which eventually leads to irreversible cell injury.

Stohs and Bagchi [47] demonstrated that cadmium is a potent cell poison and its toxicity was mediated by the oxidative damage of essential cellular macromolecules. Other reports demonstrate that $\mathrm{Cd}$ induces oxidative stress in blood and tissues by increasing lipid peroxidation and by altering the antioxidant status $[48,49]$. The brain, off all the organs, is thought to be vulnerable to oxidative damage due to its high oxygen consumption, presence of high concentrations of polyunsaturated fatty acids and nondegenerative nature of neurons, which may lead to various neurodegenerative diseases [50,51].

It has been proposed that $\mathrm{Cd}$ may initiate oxidative stress through the following two pathways:1) depletion antioxidant enzymes [28,52] and 2) enhancing production of reactive oxygen species, both in vitro and in vivo [53,54].

The morphological investigations of the current study revealed different changes in the lungs and brain. Lung lesions are consisting of vascular severe inflammation in both alveoli and bronchioles with edema and congestion. These pathological changes are in agreement with the findings of Shin et al. [55] who reported that the lung is a primary target organ of systemic exposure to cadmium. Because cadmium is mainly absorbed through the inhalation of industrial pollution and tobacco smoke, the result is the accumulation of this metal in the lung. Also, Yamada et al. [56] noticed a dramatic increase in the number of alveolar neutrophilic leukocytes 6-48 h after intra-bronchial instillation of $1 \mathrm{mg}$ cadmium chloride into lungs of dogs. Bell et al. [57] reported that $\mathrm{Cd}$ exposure was deleterious to the lung tissue causing mild to severe inflammation in the lung. However, inhalation of $\mathrm{Cd}$ has been implicated in the development of emphysema and pulmonary fibrosis [58]. Mckenna et al. [5] reported that Cd-exposed lungs showed acute and more chronic pulmonary inflammation in both rats and mice with bronchiolar and alveolar lesions.

Administration of $\mathrm{Cd}$ induced morphopathological changes in the brain involved different types of neurons in 


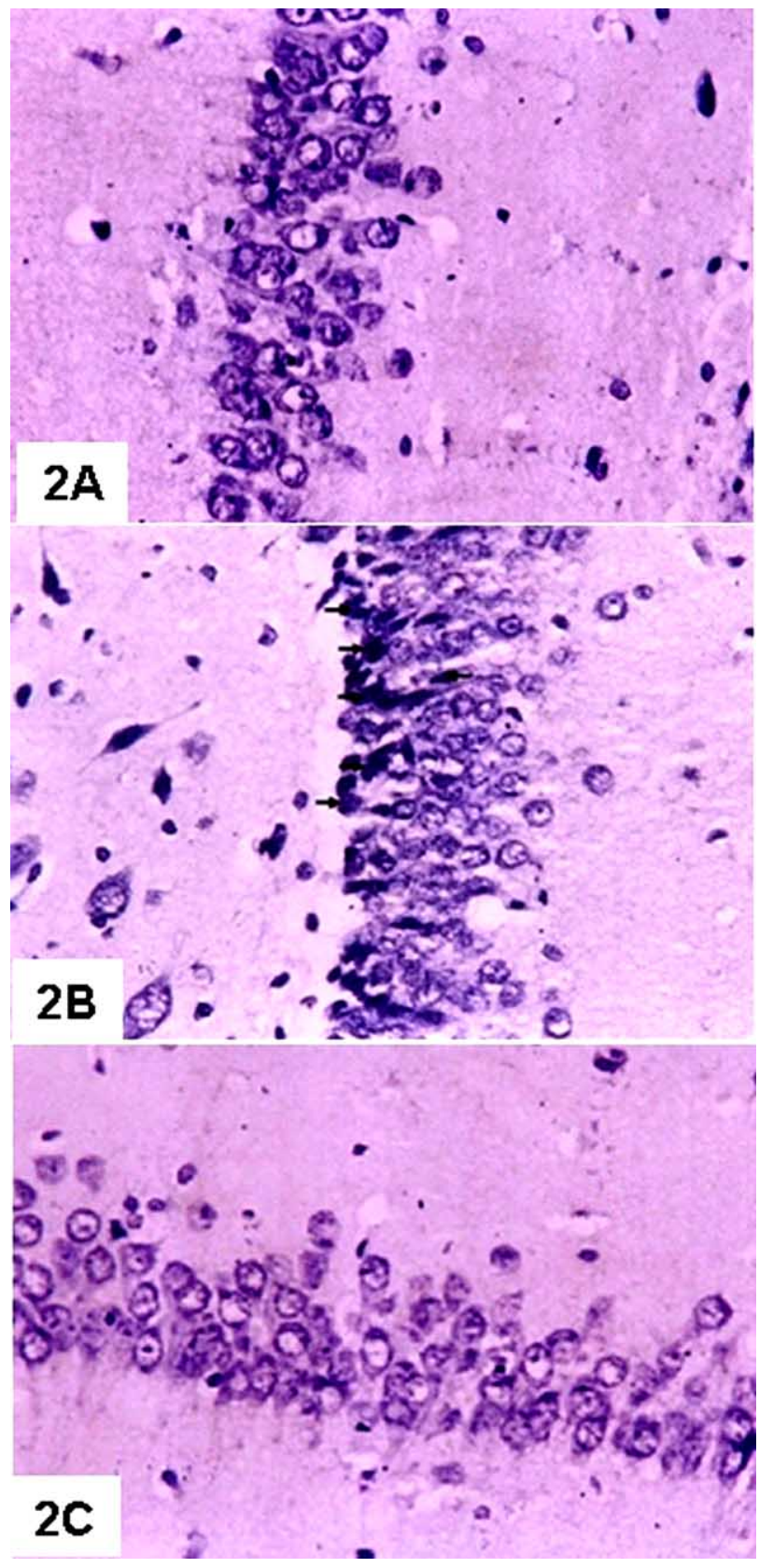

Fig. (2). (A) T. S of brain of a control rat showing granular layer of the hippocampus with normal neurons. The nuclei are vesicular. (H\&E X 400). (B) T. S of brain of Cd-treated rat showing granular layer of the hippocampus with predominantly shrinkage, pyknotic and deeply-stained neurons (arrows). (H\&E X 400). (C) T. S of brain of $\mathrm{VC}+\mathrm{Cd}$-treated rat showing granular layer of the hippocampus with normal appearance of the majority of neurons. (H\&E X 400).

the examined regions (hippocampus and cerebral cortex). The neurons undergo either degenerative or apoptotic changes. The degenerative changes manifested by shrinkage and deeply stained neurons in both studied regions. These observations in harmony with experimental studies in the CNS of newborn rats and rabbits exposed to high doses of $\mathrm{Cd}$, which showed extensive hemorrhage in the cerebral and cerebellar cortices, several pyramidal cells with pyknotic nuclei, neuroglial cells with cytolysis and altered purkinje cells $[59,60]$. It was reported that $\mathrm{Cd}$ has distinct neurotoxic effects in adults and newborn animals. In adult rats, high doses of $\mathrm{Cd}$ produce damage to the Gasserian and sensory spinal ganglia, but in newborn rats, high doses of $\mathrm{Cd}$ produce severe hemorrhagic lesions in cerebrum and cerebellum [59]. Also, $\mathrm{Cd}$ is a highly toxic metal; in particular, it was reported to produce neuropathological and neurochemical alterations in the central nervous system resulting in irritability and hyperactivity [61].

The necrotic and degenerative changes of brain may be attributed to the high susceptibility of rats to $\mathrm{Cd}$ toxicity and it was considered an important indication for neuro-toxic effect of $\mathrm{Cd}$ due to oxidative stress induction. This interpretation is confirmed by Williams [62] who reported that oxidative stress is one of the mechanisms that contribute to structural changes and it plays an important role in neurodegeneration.

Recent experiments have implicated the importance of antioxidant such as vitamins in protecting living organism against the toxic effects of environmental chemicals [63]. Free radical scavengers and antioxidants, such as glutathione, vitamin $\mathrm{E}$, vitamin $\mathrm{C}$ are capable of protecting against $\mathrm{Cd}$ toxicity [64]. Vitamin $\mathrm{C}$ is an important dietary antioxidant and in the general absence of metal ion-catalyzed reactions, it is qualitatively the single most important plasma antioxidant. Thus vitamin $\mathrm{C}$ has been used as a choice of antioxidants in vitro [65]. It has been known to protect all classes of lipids from oxidation under a number of relevant types of oxidant stress while other non- enzymatic antioxidants such as vitamin A, Vitamin E, glutathione, bilirubin, and urate merely lower the rate of oxidation or act in a more restricted [66]. Vitamin $\mathrm{C}$ is an important dietary antioxidant and significantly decreases the adverse effect of reactive species such as reactive oxygen that can cause oxidative damage to macromolecules such as lipids, DNA and proteins which are implicated in several diseases [67].

In the present investigation, vitamin $\mathrm{C}$ maintained the levels of LPO, SOD activity and GSH concentration produced in the lungs and brain nearly at control values. Accordingly, vitamin $\mathrm{C}$ inhibited the increase of LPO levels (by $47.4 \%$ and $45.8 \%$ ) in both lungs and brain at respectively and this inhibition was significant $(\mathrm{p}<0.05)$. The inhibiting effect of vitamin $\mathrm{C}$ on lipid peroxidation resulting from cadmium toxicity corresponds well to the finding of Gupta and Kar [33] and Gupta et al. [68] who proposed that Vitamin C supplementation helped to reduce MDA levels and at the same time increased the activity of antioxidant enzymes such as superoxide dismutase and glutathione peroxide in Cd-exposed rats. Also, Halliwell et al. [32] reported that vitamin $\mathrm{C}$ scavenges the aqueous ROS by very rapid electron transfer that inhibit LPO. In addition, studies of Rodriguez-Martinez et al. [69] and Muthuvel et al. [50] revealed that vitamin $\mathrm{C}$ acts against oxidative stress in central nervous system

In the current study, vitamin $\mathrm{C}$ markedly reduced the histopathological changes induced by cadmium chloride in both lungs and brain (hippocampus and cerebral cortex) which had normal appearance on examination. These observations are in agreement with Oski [70] who recorded 


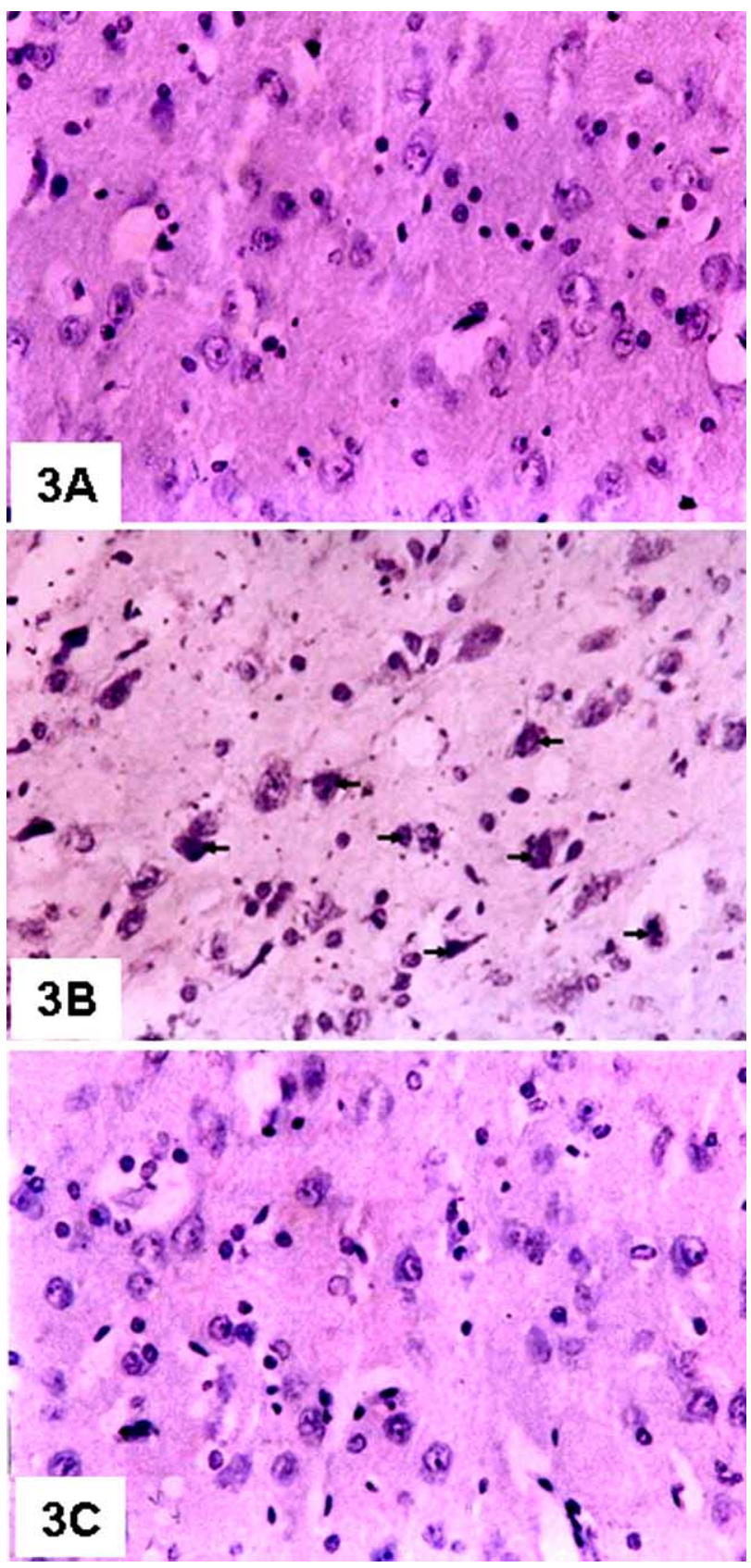

Fig. (3). (A) T. S of brain of a control rat showing the cerebral cortex with normal neurons. (H\&E X 400). (B) T. S of brain of Cdtreated rat showing the cerebral cortex with predominantly shrinkage, pyknotic, necrosed and deeply-stained neurons (arrows). (H\&E X 400). (C) T. S of brain of VC+Cd-treated rat showing the cerebral cortex with normal appearance of the majority of neurons. (H\&E X 400).

that highly unstable free radicals attack the polyunsaturated fatty acids of membrane phospholipids, and can damage both the structure and function of cell membranes in a chain reaction unless they are quenched by an antioxidant. Administration of a moderately large dose of vitamin $\mathrm{C}$ almost completely prevents protein damage, apoptosis and the lung injury [71]. Moreover, population surveys have linked a low dietary intake of vitamin $\mathrm{C}$ with worse lung function [72]. In addition, antioxidants have therapeutic importance in neurological disorders where oxidative stress is involved [73]. The antioxidant potential of ascorbic acid is not only attributed to its ability to quench reactive oxygen species, but also to its ability to generate other small molecule antioxidants, such as $\alpha$ tocopherol, glutathione and B-carotene [74].

In conclusion, the results of the current study suggest that vitamin $\mathrm{C}$ is useful and effective antioxidant against the toxicity induced by $\mathrm{CdCl}_{2}$ in lungs and brain of rats. Thus vitamin $\mathrm{C}$ can be used in co-treatment of cadmium poisoning, since it has the capability to alleviate many of the harmful effects of cadmium.

\section{REFFERENCES:}

[1] Sherlock JC. Cadmium in foods and the diet. Experientia 1984; 40: 152-56.

[2] Page AL, Al-Amamy, MM, Chang AC. Cadmium: Cadmium in the environment and its entry into terrestrial food chain crops. SringerVerlag, Berlin: Heideiberg, New York; 1986; pp. 33-74.

[3] Hart BA. Response of the respiratory tract to cadmium.In: Zalpus. RK, Koropatnick J, Eds. Molecular Biology and toxicology of metals. London. UK: Taylor and Francis 2000; pp 208-33.

[4] Office of Environmental Health Hazard Assessment (OEHHA). Public health goal for cadmium in drinking water, February 1999.

[5] Mckenna IM, Waalkes MP, Chen LC, Grdn T. Comparison of inflammatory lung responses in Wister rats and C57 and DBA mice following acute exposure to cadmium oxide fumes. Toxicol Appl Pharmacol 1997; 146: 196-206.

[6] Stohs SJ, Bagchi D, Bagchi M. Toxicity of trace element in tobacco smoke. Inhal Toxicol 1997; 9: 867-90.

[7] Manca D, Ricard AC, Trottier B, Chevalier G. Studies on lipid peroxidation in rat tissues following administration of low and moderate doses of cadmium chloride. Toxicology 1991; 67: 30323.

[8] Manca D, Ricard AC, Tra HV, Chevalier G. Relation between lipid peroxidation and inflammation in the pulmonary toxicity of cadmium. Arch Toxicol 1994; 68: 364-69.

[9] Ercal N, Gurer-Orhan H, Aykin-Burns N. Toxic metals and oxidative stress. Part 1. Mechanisms involved in metal-induced oxidative damage. Curr Top Med Chem 2001; 1: 529-39.

[10] Luchese C, Brandao R, de Oliveira R, Nogueira WC, Santos WC. Efficacy of diphenyl diselenide against cerebral and pulmonary damage induced by cadmium in mice. Toxicol Lett 2007; 173: 18190.

[11] Luchese C, Pinton S, Nogueira WC. Brain and lungs of rats are differently affected by cigarette smoke exposure: antioxidant effect of an organoselenium compound. Pharmacol Res 2009; 59: 194201.

[12] Waisberg M, Joseph P, Hale B, Beyersmann D. Molecular and cellular mechanisms of cadmium carcinogenesis. Toxicology 2003; 192: 95-117.

[13] Newman L, Metals. Occupational and Environmental Respiratory Disease, 1st ed. In: Harber P, Schenker MB, Balmes J, Eds. MO: Mosby St. Louis 1996; pp. 469-513.

[14] Fernandez MA, Sanz P, Palomar M, Serra J, Gadea E. Fatal chemical pneumonitis due to cadmium fumes. Occup Med 1996; 46: 372-74.

[15] Monroe KR, Halvorsen WS. Cadmium blocks receptor-mediated Jak/STAT signaling in neurons by oxidative stress. Free Radic Biol Med 2006; 41: 493-502.

[16] Pajovic SB, Saicic ZS, Sasic MB, Petrovic MB. The effect of ovarian hormones on antioxidant enzyme activities in the brain of male rats. Physiol Rev 2003; 52; 189-94.

[17] Shukla A, Shukla SG, Srimal RC. Cadmium induced alterations in blood-brain barrier permeability and its possible correlation with decreased microvessel antioxidant potential in rat. Hum Exp Toxicol 1996; 15: 400-5.

[18] Pal R, Nath R, Gill DK. Influence of ethanol on cadmium accumulation and its impact on lipid peroxidation and membrane bound functional enzymes $(\mathrm{Na}+, \mathrm{K}+$, ATPase and acetylcholinesterase) in various regions of adult rat brain . Neurochem Int 1993; $23: 451-58$. 
[19] Méndez-Armenta M, Villeda-Hernandez J, Barroso-Moguel R, Nava-Ruiz C, Jimenez-Cadeville ME, Rios C. Brain regional lipid peroxidation and metallothionein levels of developing rats exposed to cadmium and dexamethasone. Toxicol Lett 2003; 144: 151-57.

[20] López E, Arce C, Oset-Gasque MJ, Canadas S, Gonzalez MP. Cadmium induces reactive oxygen species generation and lipid peroxidation in cortical neurons in culture. Free Radic Biol Med 2006; 40: 940-51

[21] Takiguchi M, Yoshihara S. New aspects of cadmium as endocrine disruptor. Environ Sci 2006; 13: 107-16.

[22] Nishimura Y, Yamaguchi JY, Kanada A, et al. Increase in intracellular $\mathrm{Cd}(2+)$ concentration of rat cerebellar granule neurons incubated with cadmium chloride: cadmium cytotoxicity under external Ca (2+)- free condition. Toxicol In vitro 2006; 20: 211-16.

[23] Rose CS, Heywood PG, Costanzo RM1992. Olfactory impairment after chronic occupational cadmium exposure. J Occup Med 1992; 34: 600-5

[24] Lukawski K, Nieradko B, Sieklucka-Dziuba M. Effects of cadmium on memory processes in mice exposed to transient cerebral oligemia. Neurotoxicol Teratol 2005; 27: 575-84.

[25] Mendez-Armenta M, Rios C. Cadmium toxicity. Environ Toxicol Pharmacol 2007; 23: 350-58.

[26] Viaene MK, Masschelein R, Leenders J, Groof M, De Swerts LJV, Rels HA. Neurobehavioural effects of occupational exposure to cadmium: a cross sectional epidemiological study. Occup Environ Med 2000; 57: 19-27

[27] Gutierrez-Reyes E, Albores A, Rios C. Increase of striatal dopamine release by cadmium in nursing rats and its prevention by dexamethasone-induced metallothionein. Toxicology 1998; 131: 145-54.

[28] Valko M, Rhodes CJ, Moncol J, Izakovic M, Mazur M. Free radicals, metals and antioxidants in oxidative stress-induced cancer. Chem Biol Interact 2006; 160: 1-40.

[29] El-Sokkary GH, Nafady AA, Shabash EH. Melatonin ameliorates cadmium-induced oxidative damage and morphological changes in the kidney of rat. Open Neuroendocrinol J 2009; 2: 1-9.

[30] El-Sokkary GH, Nafady AA, Shabash EH. Melatonin administration ameliorates cadmium-induced oxidative stress and morphological changes in the liver of rat. Ecotoxicol Environ Saf 2010; 73: 456-63

[31] Suberlich HA. Pharmacolgy of vitamin C. Annu Rev Nutr 1994; 14: 371-91.

[32] Halliwell B, Wasil M, Grootveld M. Biologically significant scavenging of the myeloperoxidase-derived oxidant hypochlorous acid by ascorbic acid. FEBS Lett 1987; 213: 15-17.

[33] Gupta P, Kar A. Role of ascorbic acid in cadmium-induced thyroid dysfunction and lipid peroxidation. J Appl Toxicol 1998; 18: 31720.

[34] Zaidi SMK, Banu N. Antioxidant potentials of vitamins A, E and C in modulating oxidative stress in rat brain. Clin Chem Acta 2004; 340: 22-33.

[35] El-Sokkary GH. Melatonin and vitamin $\mathrm{C}$ administration ameliorate diazepam-induced oxidative stress and cell proliferation in the liver of rats. Cell Prolif 2008; 41: 168-76.

[36] Ohkawa H, Ohishi N, Nagi K. Assay for lipid peroxides in animal tissues by thiobarbituric acid reaction. Anal. Biochem. 1979; 95: 351-58.

[37] Misra HP, Fridovich I. The role of superoxide anion in the autoxidation of epinephrine and a simple assay for superoxide dismutase. J Biol Chem 1992; 247: 3170-75.

[38] Beutler E, Duron O, Kelly BM. Improved method for the determination of blood glutathione. J Lab Clin Med 1963; 61: 88288 .

[39] Bradford M. Rapid and sensitive method for quantitation of protein utilizing the principle of protein-day binding. Analytical Biochem 1976; 72: 248-54.

[40] Gabe M. Histological Techniques. Paris: Masson / New York, Heidelberg and Berlin: Springer-Verlag 1976.

[41] Kwon KY, Jang JH, Kwon SY, Cho CH., Oh HK, Kim SP. Cadmium induced acute lung injury and TUNEL expression of apoptosis in respiratory cells. J Korean Med Sci 2003; 18: 655-62.

[42] Bagchi D, Josh, SS, Bagchi M, et al. Cadmium and chromiuminduced oxidative stress, DNA damage, and apoptotic cell death in cultured human chronic myelogenous leukemic K562 cells, promylocytic leukemic HL-60 cells, and normal human peripheral blood mononuclear cells. J Biochem Mol Toxicol 2000; 14: 33-41.
[43] Jamal IS, Smith JC. Effects of cadmium on glutathione peroxidase, superoxide dismutase and lipid peroxidation in the rat heart: A possible mechanism of cadmium cardiotoxicity. Toxicol Appl Pharmacol 1985; 80: 33-42.

[44] Szuster-Ciesielska A, Stachura A, Slotwinska M, et al. The inhibitory effect of zinc on cadmium-induced cell apoptosis and reactive oxygen species (ROS) production in cell cultures. Toxicology 2000; 145: 159-71.

[45] Dickinson PJ, Carrington AL, Fros, GS, Boulton AJM Neurovascular disease, antioxidants and glycation in diabetes. Diabetes Metab Res Rev 2002; 18: 260-72.

[46] Yang CF, Shen HM, Shen Y, Zhuang ZX, Ong CN. Cadmiuminduced cellular damage in human fetal lung fibroblasts (MRC-5 cells). Environ Health Perspect 1997; 105: 712-16.

[47] Stohs SJ, Bagchi D. Oxidative mechanisms in the toxicity of metal ions. Free Radic Biol Med 1995; 18: 321-36.

[48] El-Demerdash FM, Yousef MI, Kedwany FS, Baghdadi HH. Cadmium-induced changes in lipid peroxidation, blood hematology, biochemical parameters and semen quality of male rats: protective role of vitamin $\mathrm{E}$ and $\mathrm{B}$-carotene. Food Chem Toxicol 2004; 42: 1563-71.

[49] Uchida M, Teranishi H, Aoshima K, Katoh T, Kasuya M, Inadera $\mathrm{H}$. Reduction of erythrocyte catalase and superoxide dismutase activities in male inhabitants of a cadmiumpolluted area in Jinzu river basin. J Toxicol Lett 2004; 151: 451-57.

[50] Muthuvel R, Venkataraman P, Krishnamoorthy G, et al. 2006 Anti-oxidant effect of ascorbic acid on PCB (Aroclor 1254) induced oxidative stress in hypothalamus of albino rats. Clin Chim Acta 2006; 365: 297-303.

[51] Halliwell B, Gutteridge JMC. Free radicals in biology and medicine. 4th ed. Oxford/UK:Clarendon Press/Oxford Science 2007.

[52] Stohs SJ, Bagchi D, Hassoun E, Bagchi M. Oxidative mechanisms in the toxicity of chromium and cadmium ions. J Environ Pathol Toxicol Oncol 2001; 20: 77-88.

[53] Filipic M, Hei TK. Mutagenicity of cadmium in mammalian cells: implication of oxidative DNA damage. Mutat Res 2004; 546: 8191.

[54] Watjen W, Beyersmann D. Cadmium-induced apoptosis in C6 glioma cells: influence of oxidative stress. Biometals 2004; 17: 6578.

[55] Shin H, Lee B, Yeo MG, et al. Induction of orphan nuclear receptor Nur77 gene expression and its role in cadmium-induced apoptosis in lung. Carcinogenesis 2004; 25: 1467-75.

[56] Yamada H, Damiano VV, Meranze DR, Glasgow J, Abrams WR, Weinbaum G. Neutrophil degranulation in cadmium chloride induced acute lung inflammation. Am J Pathol 1992; 109: 145-56.

[57] Bell RR, Nonavinakere VK, Soliman MR. Intratracheal exposure of the guinea pig lung to cadmium and/or selenium: a histological evaluation. Toxicol Lett 2000; 114: 101-9.

[58] Driscoll KE, Maurer JK, Poynter J, Higgins J, Asquith T, Miller NS. Stimulation of rat alveolar macrophage fibronectin release in a cadmium chloride model of lung injury and fibrosis. Toxicol Appl Pharmacol $1992 ; 116: 30-37$.

[59] Wong KL, Cachia R, klaassen CD. Comparison of the toxicity and tissue distribution of cadmium in newborn and adult rats after repeated administration. Toxicol Appl Pharmacol 1980 ; 56 : 31725 .

[60] Méndez-Armenta M, Barroso-Moguel R, Villeda-Hernandez J, Nava-Ruiz C, Rios C. Histopathological alterations in the brain regions of rats after perinatal combined treatment with cadmium and dexamethasone. Toxicology 2001; 161: 189-199.

[61] Antonio M, Corpas I, Laret ML. Neurochemical changes in newborn rat's brain after gestational cadmium and lead exposure. Toxicol Lett 1999; 104: 1-9.

[62] Williams LR. Oxidative stress, age-related neurodegeneration, and the potential for neurotrophic treatment. Cerebrovasc. Brain Metab Rev 1995; 7: 55-73.

[63] Na N, Delanghe JR, Taes YEC, Torck M, Baeyens WRG, Ouyang J. Serum vitamin $C$ concentration is influenced by hepatoglobin polymorphism and iron status in Chinese. Clin Chim Acta 2006; 365: 31-324.

[64] Peters JM, Duncan JR, Wiley LM, Keen CL. Influence of antioxidants on cadmium toxicity of mouse preimplantation embryos in vitro. Toxicology 1995; 99: 11-18. 
[65] Kang SA, Jang YJ, Park H. In vivo dual effects of vitamin C on paraquat-induced lung damage: dependence on released metals from the damaged tissue. Free Radic Res 1998; 28: 93-107.

[66] Coa G, Booth SL, Sadowski JA, Prior RL. Increases in human lasma antioxidant capacity after consumption of controlled diets high in fruit and vegetables. Am J Clin Nutr 1998; 68: 1081- 87.

[67] You WC, Zhang L, Gail MA, et al. Gastric cancer: Helicobacter pylori, serum vitamin C, and other risk factors. J Natl Cancer Inst 2000; 2: 1607-12.

[68] Gupta RS, Gupta ES, Dhakal BK, Thakur AR, Ahnn J. Vitamin C and vitamin $\mathrm{E}$ protect the rat testes from cadmium-induced reactive oxygen species. Mol Cell 2003; 17: 132-39.

[69] Rodriguez-Martinez E, Rugerio-Vargas C, Rodriguez AL, Borgonio-Perez G, Rivas-Arancibia S. Antioxidant effects of taurine, vitamin $\mathrm{C}$ and vitamin $\mathrm{E}$ on oxidative damage in hippocampus caused by the administration of 3-nitropropionic acid in rats. Int J Neurosci 2004; 114: 1133-45.

[70] Oski FA. Vitamin E-A radical defense. N Engl J Med 1980; 303: 454-55.

[71] Banerjee S, Chattopadhyay R, Ghosh A, et al. Cellular and molecular mechanisms of cigarette smoke-induced lung damage and prevention by vitamin C. J Inflamm 2008; 11: 5-21.

[72] Schunemann HJ, Freudenheim JL, Grant BJ. Epidemiologic evidence linking antioxidant vitamins to pulmonary function and airway obstruction. Epidemiol Rev 2001; 23: 248-67.

[73] Law A, Gauthier S, Quuirion R. Neuroprotective and neurorescuing effects of isoform-secific nitric oxide synthase inhibitors, nitric oxide scavenger, and antioxidant against betaamyloid toxicity. Br J Pharmacol 2001; 133: 1114-24.

[74] Evans P, Halliwell B. Micronutrients: oxidant/ antioxidant status. Br J Nutr 2001; 85: 567-74.

Received: July 25, 2010

Revised: November 01, 2010

Accepted: November 02, 2010

(c) El-Sokkary and Awadalla; Licensee Bentham Open.

This is an open access article licensed under the terms of the Creative Commons Attribution Non-Commercial License (http://creativecommons.org/licenses/by-nc/3.0/) which permits unrestricted, non-commercial use, distribution and reproduction in any medium, provided the work is properly cited. 